https://doi.org/10.46813/2021-136-201

\title{
FORMATION AND MONITORING OF SECONDARY X-RAY RADIATION UNDER PRODUCT PROCESSING WITH ELECTRON BEAM
}

\author{
R.I. Pomatsalyuk, V.A. Shevchenko, D.V. Titov, A.Eh. Tenishev, V.L. Uvarov, \\ A.A. Zakharchenko, V.N. Vereshchaka \\ National Science Center “Kharkov Institute of Physics and Technology”, Kharkiv, Ukraine \\ E-mail: rompom@kipt.kharkov.ua
}

\begin{abstract}
When conducting an industrial radiation processes at an electron accelerator, a part of the beam energy is transformed into bremsstrahlung radiation. In such a way, the mixed e,X-radiation is formed in the area behind an irradiated object. The intensity of the electron and photon components in the radiation is determined by the energy and power of the primary electron beam, as well as by the parameters of the object and devices located behind it. In paper, the characteristics of the e,X-radiation accompanying the product processing by a scanning electron beam with energy $8 \ldots 12 \mathrm{MeV}$ at a LU-10 Linac of NSC KIPT are studied. The conditions for obtaining a source of secondary $\mathrm{X}$-rays in the state of electronic equilibrium, as well as its monitoring using an extended free-air ionization chamber are explored. Such an extra-source of radiation can be used for carrying out various non-commercial programs like radiation tests, sanitization of archival materials and cultural heritage objects, etc.
\end{abstract}

PACS: 87.56.bd; 41.50.+h; 81.40.Wx; 87.53Bn

\section{INTRODUCTION}

High-power electron accelerators with beam energy $\sim 10 \mathrm{MeV}$ are widely used in radiation-technological processes, mainly, for sterilization of medical devices, as well as of products and feed stocks of pharmaceutical and food industry, etc. [1]. In the majority of cases, the processing is carried out directly by an electron beam. If there is a necessity of debacterization of a load with high surface density $\left(>10 \mathrm{~g} / \mathrm{cm}^{2}\right)$, the electron radiation is preliminary transformed into X-rays having higher penetration ability. For this, a special intermediate targetconverter maid from a high- $\mathrm{Z}$ material is used. Considering the requirement of even absorbed dose distribution in a processed object, the efficiency of the primary beam energy utilization is commonly not higher than $40 \%$ under treatment by electrons [2] and $10 \%$ for X-rays [3].

In work [4], a concept of a plant realizing simultaneously a two-beam e,X-regime by using bremsstrahlung radiation, generated in the interaction of electron beam with the irradiated object and devices positioned behind it, was proposed. So those elements can be considered as the constituents of an extended converter, in which the consecutive transformation of electron beam into mixed e,X-radiation takes place. The intensity of the electron component in the latter decreases with the rise of thickness of the interaction region. In turn the Xray component increases at first reaching maximum and then goes down as a result of photon absorption. The region of maximum ratio of the total photon energy to the total energy of the secondary electrons corresponds to a state of electronic equilibrium.

The e,X-radiation can be described with the use of a limited set of key parameters [4]. Those characteristics, in particular, are the ratio of total energy of bremsstrahlung photons $E_{X}$, passing a specified plane, to the total energy of the primary electron beam $E_{b}$ (the coefficient of energy conversion), and also the ratio of $E_{X}$ to the total energy of the secondary electrons $E_{e}$ passing the same plane (the factor of secondary radiation). As the universal length of a path of the e,X-radiation formation, the sum of thicknesses of the its constituents expressed in the units of the extrapolated range of electrons $R_{e}$ with primary energy $E_{0}$ in the material of a given path element (the stopping thickness unit, stu) was offered. Under such an approach, the dependences of $E_{X} / E_{b}$ and $E_{X} / E_{e}$ on $E_{0}$ take on the universal form for the materials with $Z=7 \ldots 73$ in the $E_{0}$ range $5 \ldots 100 \mathrm{MeV}$, reaching maximum at a length of the interaction region of $0.5 \ldots 0.7$ and $1.5 \ldots 1.7 \mathrm{stu}$, respectively (Fig. 1).

In the current work, the conditions of formation of secondary X-ray radiation under product processing at a LU-10 electron Linac of NSC KIPT [5] with beam energy up to $12 \mathrm{MeV}$, as well as of X-rays on-line monitoring are studied.
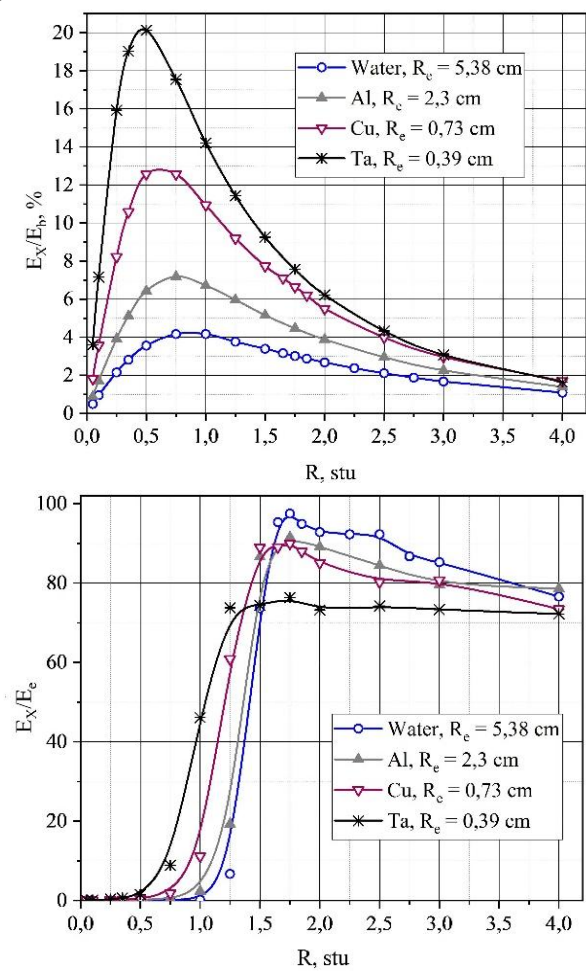

Fig.1. Dependence e,X-radiation characteristics on thickness of absorber: coefficient of energy conversion (a); factor of secondary radiation (b) 


\section{1. e,X-FLUX FORMATION}

1.1. The irradiator and exit devices of the LU-10 accelerator are located in a concrete vault (Fig. 2). A work load is transported into the irradiation zone using an overhead conveyor $\mathrm{C}$. The accelerator structure AS has a beam scanner $\mathrm{S}$ at its output controlled with PC. It provides the necessary profile of the beam sweep at an irradiated object (e-Ob). An aluminium stack-monitor SM for on-line control of beam energy and absorbed dose is positioned on the axis of the structure at a distance of $223 \mathrm{~cm}$ from the accelerator exit window [6, 7]. The SM size and thickness $(75 \times 122 \times 2.6 \mathrm{~cm})$ provide the absorption above $95 \%$ of the electron flux, an also the electronic equilibrium of gammas behind it.

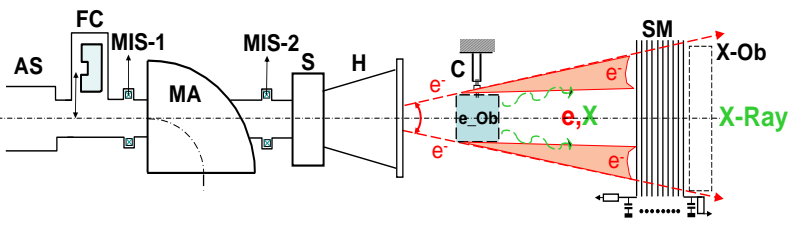

Fig. 2. Irradiator and exit devices of LU-10 accelerator

A parallel plate free-air ionization chamber IC, intended for monitoring of X-ray energy flux, follows SM. IC comprises 3 aluminium plates: the two outer by size $113 \times 77 \times 0.2 \mathrm{~cm}$ (height $\mathrm{x}$ width $\mathrm{x}$ thickness) and the inner $(113 \times 53 \times 0.1 \mathrm{~cm})$.

For the analysis and optimization of a treatment mode by secondary $\mathrm{X}$-ray radiation, an arbitrary target $\mathrm{X}$ in the form of a plate from PMMA (a standard dosimetry material [8]) was positioned behind IC. The lateral size of the plate is equal to that of SM (Fig. 3).

1.2. The study of e,X-radiation state in the elements of the formation path was conducted by a MC simulation technique on the basis of a GEANT4 transport code [9].

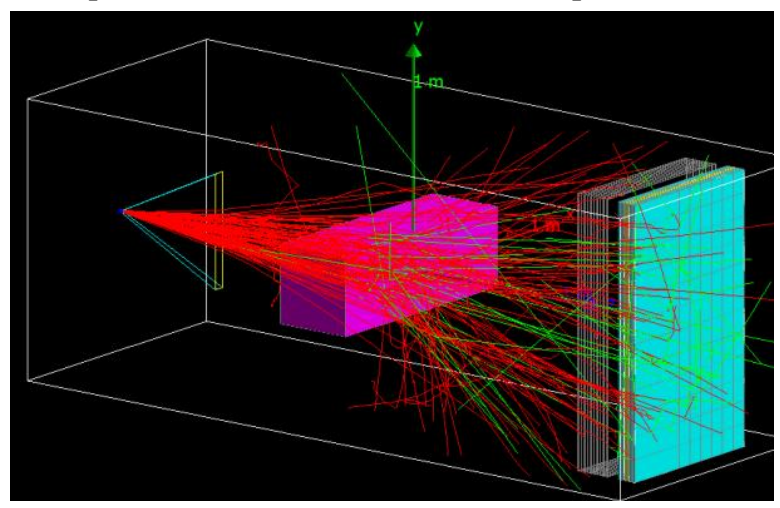

Fig. 3. Configuration of $L U-10$ exit devices in simulations

For determination of volumetric dose distribution, the $\mathrm{X}$ target by $9 \mathrm{~cm}$ in thickness was subdivided into 3 layers. In turn each layer was subdivided into the parallelepipeds by $10 \times 12 \times 3 \mathrm{~cm}$ in size.

1.3. Fig. 4 shows the results of calculation of $e, X$ radiation characteristics along the exit devices of the LU-10 machine in absence of a load in the main channel of irradiation with the electron beam (e-channel), and also in its presence. As an irradiated load (e-Ob), a phantom from cellulose by size $35 \times 105 \times 35 \mathrm{~cm}$ with nominal surface density of $4 \mathrm{~g} / \mathrm{cm}^{2}$ was considered. In calculations, the beam energy spectra corresponded to actual ones (Fig. 5).
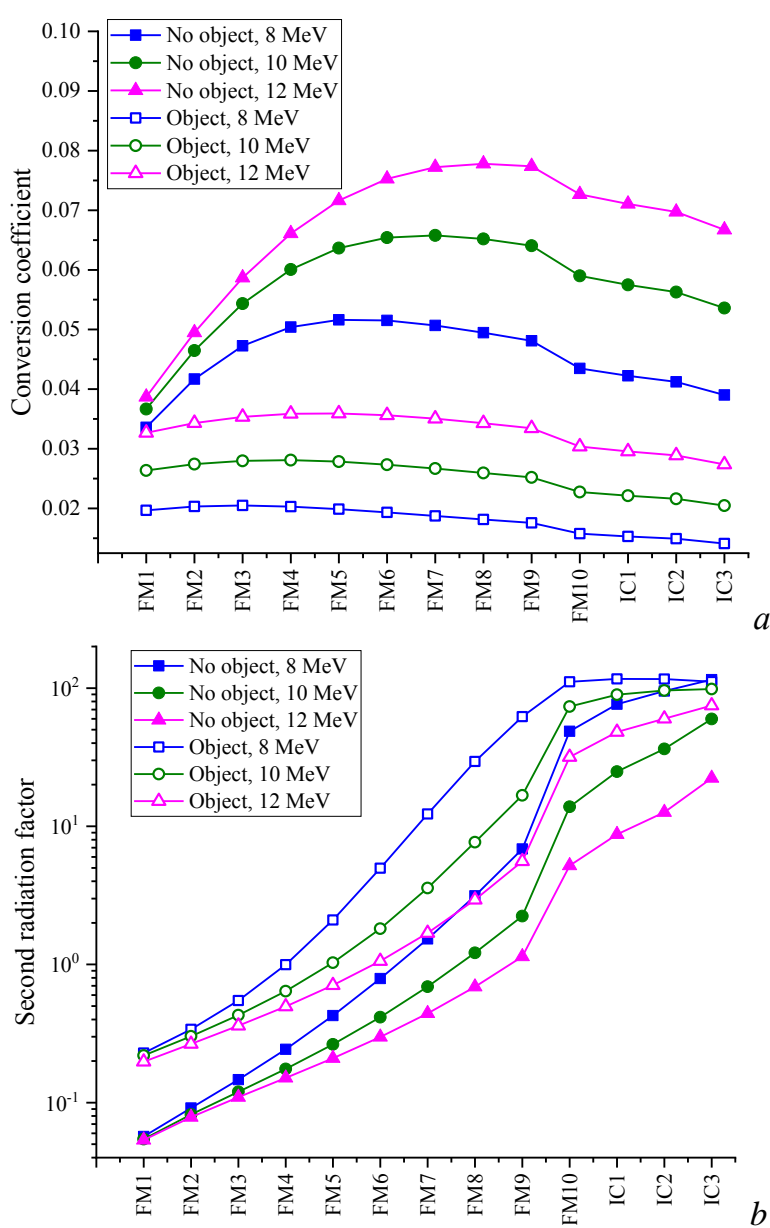

Fig.4. e,X-radiation characteristics in elements of exit devices of LU-10 accelerator: coefficient of energy conversion (a); secondary radiation factor $(b)$

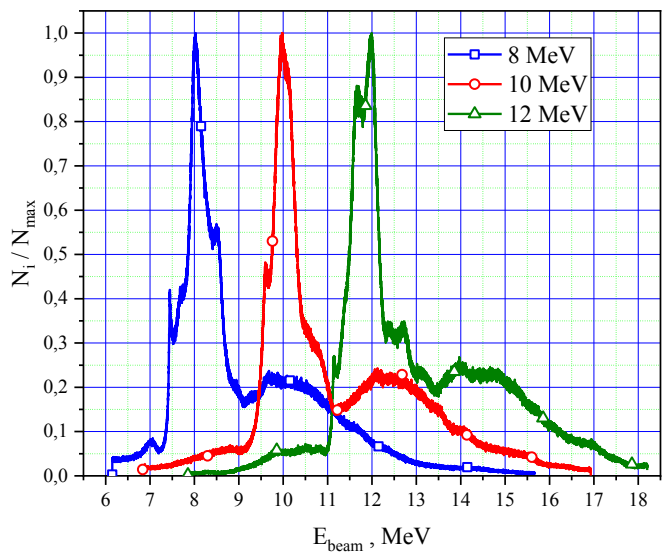

Fig. 5. LU-10 beam spectra

It is evident, that the addition of ionization chamber gives some decrease in the photon flux but the gain in the secondary radiation factor up to its correspondence to the state of electronic equilibrium. The key parameters of radiation incident on the $\mathrm{X}$ target are listed in Table 1. It is seen, that the average energy of the gammas $\langle E x\rangle$ is rather close to that of Co-60.

\section{MONITORING OF SECONDARY X-RAYS}

2.1. A circuit used for measuring the current of the ionizing chamber is presented in Fig. 6. A high-voltage supply provides the bias $200 \ldots 600 \mathrm{~V}$ of negative polarity on the inner plate of IC via a coaxial cable about $60 \mathrm{~m}$ in length. The outer plates are electrically connected 
with an integrator comprising the resistor $\mathrm{R}(12.4 \mathrm{k} \Omega)$ and capacitance $\mathrm{C}(0.47 \mu \mathrm{F})$ with time constant $5.8 \mathrm{msec}$. A signal from the integrator output connected to an automated workstation for readout with interval $2 \mathrm{sec}$ into an archiver of an EPICS system.

Table 1

Parameters of $e, X$-radiation on front surface of $X$-target

\begin{tabular}{|c|c|c|c|c|}
\hline $\begin{array}{c}\rho, \\
\mathrm{g} / \mathrm{cm}^{2}\end{array}$ & $\mathrm{Ex} / \mathrm{E}_{\mathrm{e}}$ & $\begin{array}{c}\mathrm{Ex} / \mathrm{E}_{\mathrm{b}}, \\
\%\end{array}$ & $\begin{array}{c}<\mathrm{Ex}>, \\
\mathrm{MeV}\end{array}$ & $\begin{array}{c}\text { Dmax, } \\
\mathrm{kGy} / \mathrm{h} / \mathrm{mA}\end{array}$ \\
\hline \multicolumn{5}{|c|}{$8 \mathrm{MeV}$} \\
\hline 0 & 115.3 & 3.90 & 0.835 & 10.3 \\
\hline 4 & 111.3 & 1.41 & 0.982 & 2.1 \\
\hline \multicolumn{5}{|c|}{$10 \mathrm{MeV}$} \\
\hline 0 & 59.8 & 5.36 & 0.949 & 20.2 \\
\hline 4 & 98.5 & 2.05 & 1.101 & 3.6 \\
\hline \multicolumn{5}{|c|}{$12 \mathrm{MeV}$} \\
\hline 0 & 22.3 & 6.67 & 1.040 & 40.8 \\
\hline 4 & 74.9 & 2.74 & 1.184 & 6.36 \\
\hline
\end{tabular}

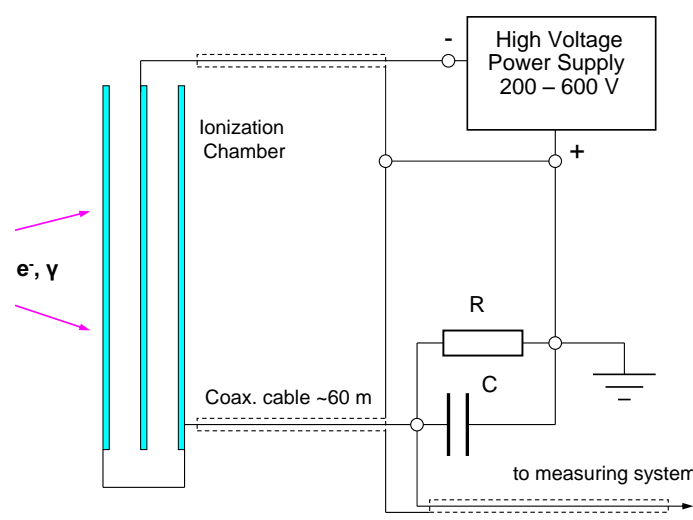

Fig. 6. IC-current measuring circuit

2.2. In the experiments, the average accelerator beam current Iacc was controlled by the pulse rate. The obtained dependence of IC current on the bias voltage at different beam pulse rate and scan width is given in Figs. 7-9. It is evident, that the IC current is proportional to the average electron beam current and tends to saturation with the rise of bias voltage. It does not depend on the beam scan width (see Fig. 9). That confirms practically full passing of X-ray flux through the ionization chamber.

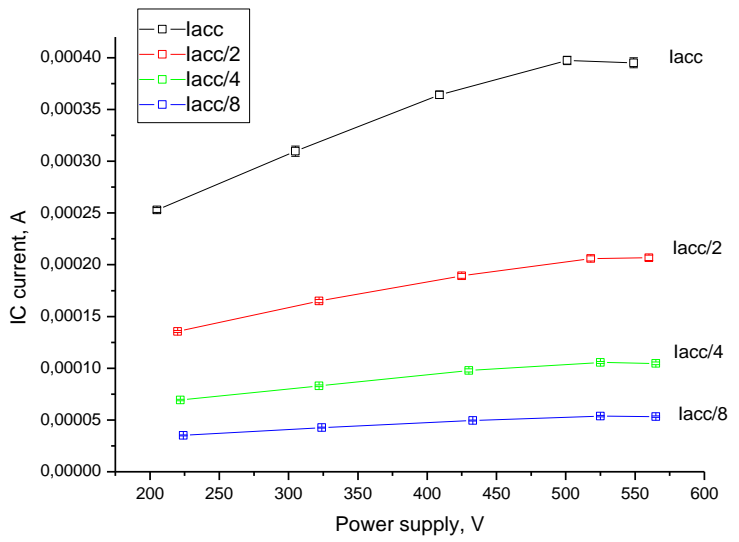

Fig. 7. Dependence of IC current on bias at different average accelerator current $($ Iacc $=0.73 \mathrm{~mA})$

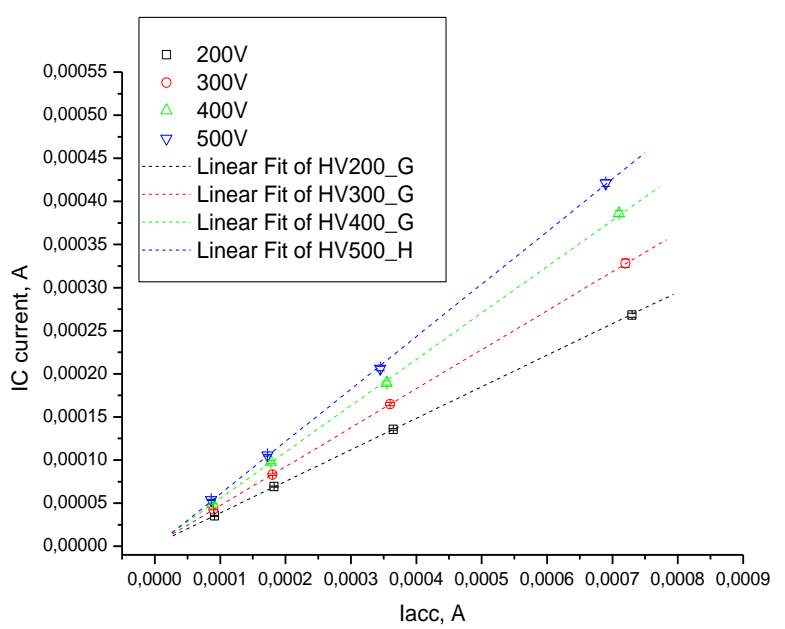

Fig. 8. Dependence of IC current on accelerator beam current at different bias voltage

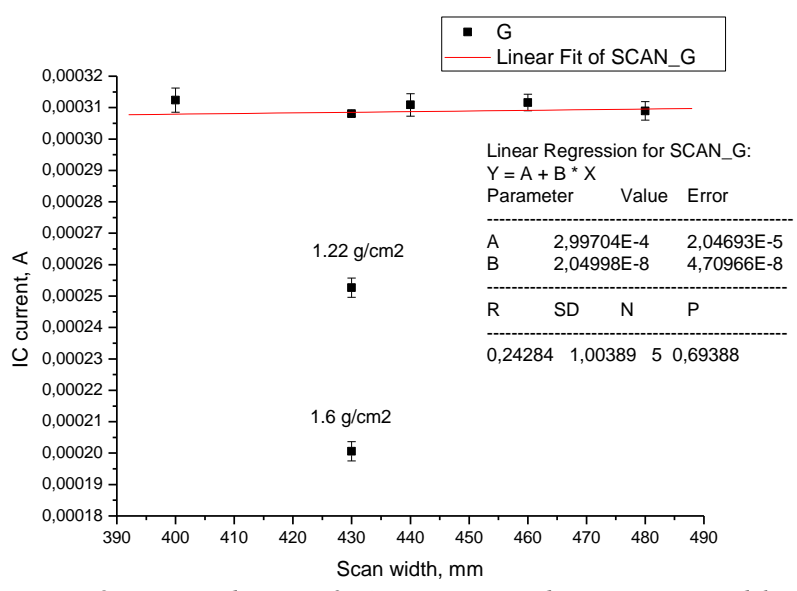

Fig. 9. Dependence of IC current on beam scan width

2.3. The dependence of IC current on the conditions of the product irradiation in the e-channel was calculated using an analytical model presented in [10] for the case of pulsed flux of gammas (Fig. 10). It is evident, that the data of calculations are underestimated by about $8 \%$ as compared with the experimental results. The systematic divergency can be explained with both the model restrictions and inaccuracy of the data on the coefficients of the charge transfer in the ionization volume of the chamber. Its proper calibration enables on-line monitoring of absorbed dose in the X-channel.

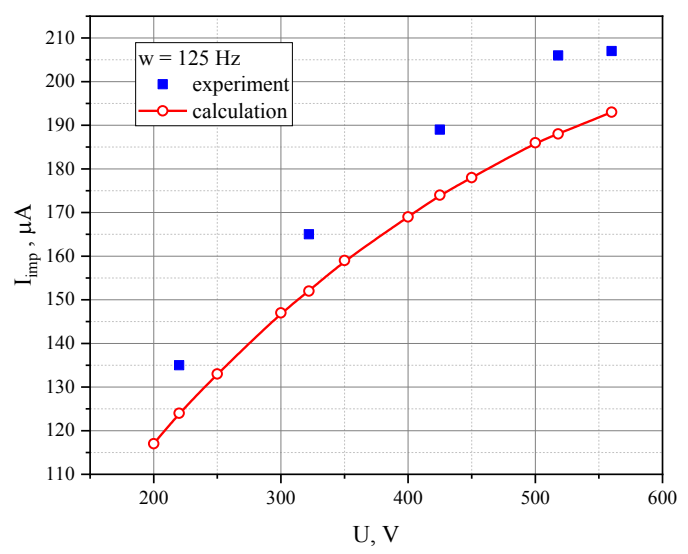

Fig. 10. Dependence of IC current on bias (comparison with model) 


\section{OPTIMIZATION OF IRRADIATION MODE IN X-CHANNEL}

3.1. A linear sweep is commonly used at product processing with the scanned electron beam to provide the even distribution of the particle density over the load surface. Conversely, it was shown in work [2], that the application of a combined scan mode, including the linear part over one half-period and the sinusoidal part over the second (Fig. 11), results in the reduction of dose ununiformity ratio (DUR) as compared with the double-linear mode. That is why the both variants of the sweep for the beam with the actual energy spectrum and similar scan amplitude were examined by the simulation technique (Fig. 12).

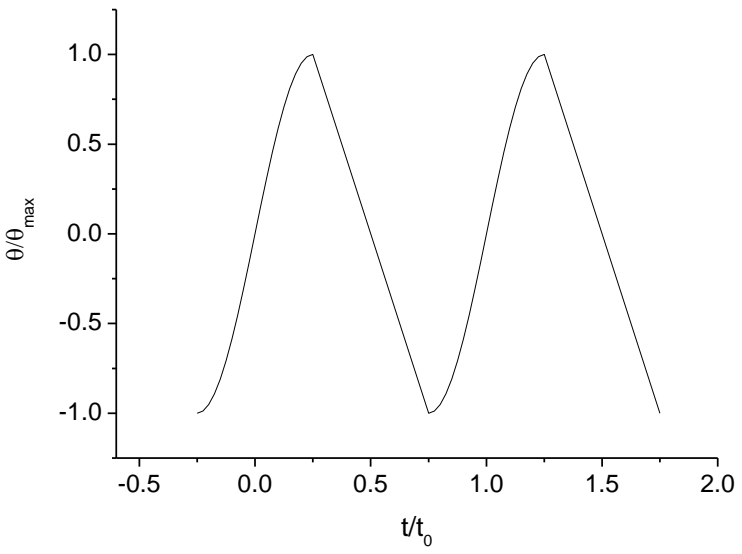

Fig. 11. Shape of combined beam sweep
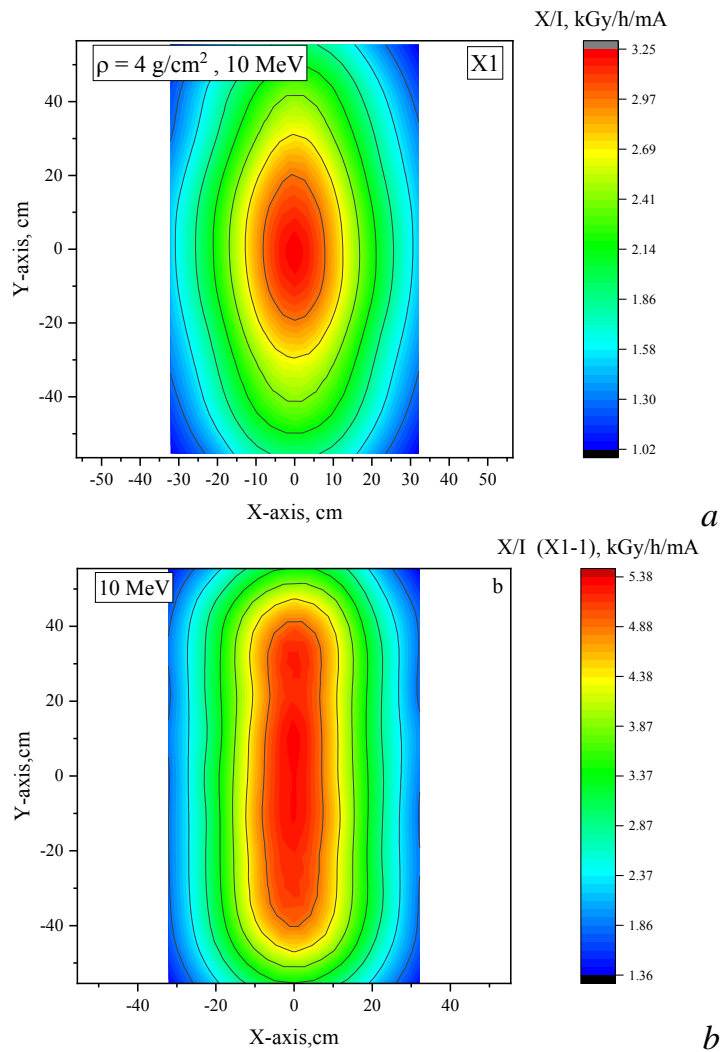

Fig. 12. Dose rate distribution in $X$ target $\left(E_{b}=10 \mathrm{MeV}\right.$, surface density of product in e-channel is $\left.4 \mathrm{~g} / \mathrm{cm}^{2}\right)$. linear sweep $(a)$; combined sweep $(b)$

It is evident, that the combined sweep flattens the dose distribution along the scanning axis. At the other hand, under the given irradiation mode and size of the target, DUR reaches 5, while its acceptable value should be not higher than 1.8 [1].

3.2. For the further smoothing of dose distribution, a two-sided irradiation mode of a target can be used, as well as the optimization of target's size. It is seen in Fig. 13, that the two-sided processing provides DUR $\leq 1.8$ along the $\mathrm{Z}$-axis of the target at its thickness of $65 \mathrm{~g} / \mathrm{cm}^{2}$.

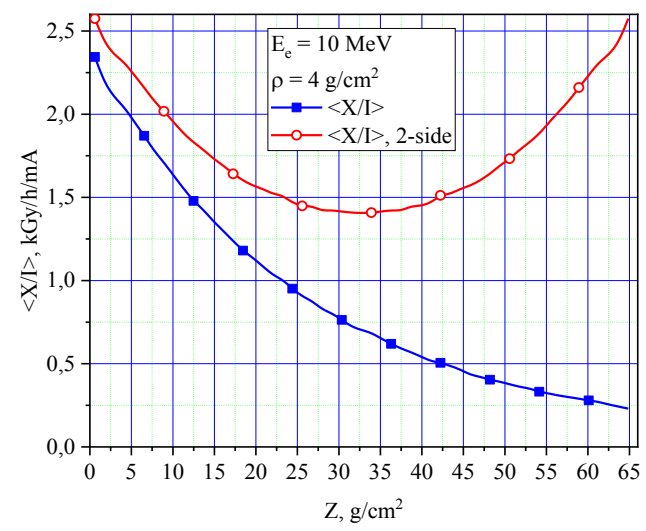

Fig. 13. Dose rate distribution along z-axis of X target for one-and two-sided irradiation

The results of estimating by MC simulation technique the X-channel capacity at a two-sided object irradiation, providing DUR not higher than 1.8, are listed in Table 2. It is evident, that the optimal size of the $\mathrm{X}$ target depends weakly on the beam energy in contrast to the throughput capacity.

Throughput capacity of X-ray channel

Table 2

\begin{tabular}{|c|c|c|c|c|c|}
\hline \multirow{2}{*}{$\begin{array}{c}\mathrm{E}_{\mathrm{e}}, \\
\mathrm{MeV}\end{array}$} & \multirow{2}{*}{$\begin{array}{c}\text { X targ. } \\
\text { size, } \\
\text { (height } \\
\times \\
\text { width), } \\
\mathrm{cm} \\
\end{array}$} & \multirow{2}{*}{$\begin{array}{c}\text { X } \\
\text { targ. } \\
\text { weig } \\
\text { ht, kg }\end{array}$} & \multicolumn{2}{|c|}{$\begin{array}{l}\text { Dose rate, } \\
\mathrm{kGy} / \mathrm{h} \cdot \mathrm{mA}\end{array}$} & \multirow{2}{*}{$\begin{array}{c}\text { X-channel } \\
\text { capacity, } \\
\mathrm{kGy} \cdot \mathrm{kg} / \mathrm{h} \text {. } \\
\mathrm{mA}\end{array}$} \\
\hline & & & Max & Min & \\
\hline 8 & $120 \times 40$ & 312 & 1.28 & 0.71 & 282 \\
\hline 10 & $120 \times 45$ & 351 & 1.98 & 1.25 & 438 \\
\hline 12 & $120 \times 50$ & 390 & 3.36 & 1.87 & 730 \\
\hline
\end{tabular}

\section{CONCLUSIONS}

Product treatment with electron beam is accompanied by generation of secondary e, X-radiation, that can be transformed into an extra-source of X-rays by the use of a set of the properly designed devices, positioned behind an irradiated load. Such a source can be applied for conducting uncommercial programs like the radiation tests, sanitization of archive materials and objects of the culture heritage, etc. Under conditions of the LU-10 Linac $(10 \mathrm{MeV}, 10 \mathrm{~kW})$ the capacity of the X-channel makes up to $440 \mathrm{kGy} \cdot \mathrm{kg} / \mathrm{mA} \cdot \mathrm{h}$. In its productivity, such a radiation channel is comparable with an X-ray source, obtained by direct conversion of electron beam of an ILU6 accelerator ( $2 \mathrm{MeV} ; 20 \mathrm{~kW}$ ), as well as with a Co-60 source having activity about $20 \mathrm{kCi}$ [12]. In particular, the extra X-ray source on the basis of the LU-10 Linac can provide the sanitization of about 80 tons of the archive materials with dose $5 \mathrm{kGy}$ and higher per a $1000 \mathrm{~h}$ beam run. 


\section{REFERENCES}

1. Industrial Radiation with Electron Beams and Xrays.

http://iiaglobal.com/uploads/documents/Industrial_R adiation_eBeam_Xray.pdf.

2. V.I. Nikiforov, R.I. Pomatsalyuk, Yu.V. Rogov, A.Eh. Tenishev, V.L. Uvarov, A.A. Zakharchenko. Analysis and Optimization of a Mode of Industrial Product Processing at an Electron Accelerator // Problems of Atomic Science and Technology. Series “Nuclear Physics Investigations”. 2015, № 6, p. 9094.

3. V.T. Lazurik, S.A. Pismenesky, G.F. Popov, D.V. Rudychev, V.G. Rudychev. An increase of utilization efficiency of X-ray beam // Radiation Physics and Chemistry. 2007, v. 76, p. 1787-1791.

4. V.L. Uvarov, A.N. Dovbnya, N.A. Dovbnya, V.I. Nikiforov. Electron Linac Based e,X-Facility // Proc. of the EPAC. 2006, p. 2257-2259.

5. V.I. Nikiforov, V.L. Uvarov. Analysis of Mixed $\mathrm{e}, \mathrm{X}$-radiation along the Extraction Facilities of Electron Accelerators // Atomic Energy. 2009, v. 106(4), p. 281-286.

6. V.N. Boriskin, S.A. Vanzha, V.N. Vereshchaka, et al. Development of radiation technologies and tests in "Accelerator" // Problems of Atomic Science and
Technology. Series "Nuclear Physics Investigations”. 2008, № 5, p. 150-154.

7. R.I. Pomatsalyuk, V.A. Shevchenko, I.N. Shlyakhov, A.Eh. Tenishev, V.Yu. Titov, D.V. Titov, V.L. Uvarov, A.A. Zakharchenko. Measurement of electron beam energy characteristics at an industrial accelerator // Problems of Atomic Science and Technology. Series "Nuclear Physics Investigations". 2017, № 6, p. 3-7.

8. R.I. Pomatsalyuk, V.A. Shevchenko, A.Eh. Tenishev, D.V. Titov, V.L. Uvarov, A.A. Zakharchenko. Development of a Method of Absorbed Dose On-line Monitoring at Product Processing by Scanned Electron Beam // Problems of Atomic Science and Technology. Series "Nuclear Physics Investigations". 2016, № 3, p. 149-153.

9. ISO/ASTM 51276:2019. Practice for Use of a Polymethylmethacrylate Dosimetry System.

10. J. Allison, K. Amako, J. Apostolakis, et al. Recent developments in Geant4 // NIM. 2016, A 835, p. 186-225.

11. V.I. Ivanov. Course of Dosimetry. "Energoatomizdat", 1988, p. 79-85 (in Russian).

12. Electron Accelerators for Research, Industry and Environment the INCT Perspective / A. Chmielewski and Z. Zimek, eds/, Warsaw, 2019, p. 28.

Article received 04.10.2021

\section{ФОРМИРОВАНИЕ И МОНИТОРИНГ ВТОРИЧНОГО ТОРМОЗНОГО ИЗЛУЧЕНИЯ ПРИ ОБРАБОТКЕ ПРОДУКЦИИ ПУЧКОМ ЭЛЕКТРОНОВ}

\section{Р.И. Помацалюк, В.А. Шевченко, Д.В. Титов, А.Э. Тенишев, В.Л. Уваров, А.А. Захарченко,}

\section{В.Н. Верещцака}

При проведении радиационно-технологических программ на ускорителе электронов часть энергии пучка трансформируется в тормозное излучение. В результате, в области за объектом формируется поток смешанного е,Х-излучения. Интенсивность его электронного и фотонного компонентов определяется энергией и мощностью первичного пучка электронов, а также параметрами объекта и размещенных за ним устройств. Изучены характеристики е,Х-излучения, которое сопровождает обработку продукции сканирующим пучком электронов с энергией 8..12 МэВ на промышленном ускорителе ЛУ-10 ННЦ ХФТИ. Исследованы условия получения источника вторичного тормозного излучения в состоянии электронного равновесия, а также его мониторинга с использованием протяженной свободно-воздушной ионизационной камеры. Такой дополнительный источник излучения может быть использован для проведения некоммерческих программ, например, радиационных испытаний, санитарной обработки архивных материалов, объектов культурного наследия и т.п.

\section{ФОРМУВАННЯ ТА МОНТОРИНГ ВТОРИННОГО ГАЛЬМІВНОГО ВИПРОМІНЮВАННЯ ПРИ ОБРОБЦІ ПРОДУКЦЇ̈ ПУЧКОМ ЕЛЕКТРОНІВ}

\section{Р.І. Помацалюк, В.А. Шевченко, Д.В. Тітов, А.Е. Тєнішев, В.Л. Уваров, А.О. Захарченко, В.М. Верещака}

При проведенні радіаційно-технологічних програм на прискорювачі електронів частина енергії пучка трансформується в гальмівне випромінювання. Як наслідок, в області за об'єктом формується потік мішаного е,Х-випромінювання. Інтенсивність його електронного та фотонного компонентів визначається енергією і потужністю первинного пучка електронів, а також параметрами об'єкта та розміщених за ним пристроїв. Досліджені характеристики е,Х-випромінювання, що супроводжує обробку продукції скануючим пучком електронів з енергією 8...12 МеВ на промисловому прискорювачі ЛП-10 ННЦ ХФТІ. Вивчені умови отримання джерела вторинного гальмівного випромінювання в стані електронної рівноваги, а також його моніторингу з використанням протяжної вільно-повітряної іонізаційної камери. Таке додаткове джерело випромінювання може бути використано для проведення різних некомерційних програм, наприклад, радіаційних випробувань, санітарної обробки архівних матеріалів, об'єктів культурної спадщини та інше. 